\title{
Effect of treatment on renal function in severe osteomalacia due to Wilson's disease
}

\author{
PAULINE MONRO \\ From Atkinson Morley's Hospital, Wimbledon, London
}

SYNOPSIS A patient with Wilson's disease presented at the age of 41 with a neurological defect and gross osteomalacia secondary to a defect of renal tubular reabsorption. He also showed the unusual features of a renal stone in the presence of the Fanconi syndrome and a $\frac{\mathbb{D}}{3}$ relatively low alkaline phosphatase level, possibly due to the additional inherited defect of ${ }_{\Phi}$ hypophosphatasia. During four years of treatment with penicillamine and calciferol clinical improvement was spectacular. Details of amino-acid clearances before and after treatment are given, and the results suggest that, as in the brain and the liver, the function of the distal renal tubules may be restored in Wilson's disease when copper is removed.

In Wilson's disease copper is deposited in the kidneys as well as in the brain and liver. Although impairment of renal tubular function may frequently be shown on testing, it is rare for the renal disturbance to predominate in the clinical picture. There have been only four previous reports of patients with Wilson's disease in whom the main presenting feature was osteomalacia secondary to failure of phosphate reabsorption by the kidneys.

Walshe (1968) has recently reported improvement in the distal tubular function of urine acidification after treatment with penicillamine, but there have been no previous detailed reports of the effect of long-term treatment on the proximal tubular function of amino-acid reabsorption.

This report is of a man with Wilson's disease who presented with both neurological signs and gross osteomalacia at the unusually late age of 41 , and on whom renal function studies, including amino-acid clearances, were performed before and after four years' treatment with penicillamine. Further unusual features were the presence of renal stones with the Fanconi syndrome, and a plasma alkaline phosphatase level which was only slightly raised despite the severe osteomalacia.

Received for publication 1 January 1970.

\section{Case History}

Mr H. never had any complaints, but probably the first evidence of mental impairment was at 27 when he lost the job he had held for 13 years. Seven years later he was permanently unemployed $:$ and was noted to be unsteady when walking. 3 . At 39 he was euphoric with a mild cerebellar $\delta$ dysarthria and ataxia. At 41 he was found living $₹$ in extreme squalor and was admitted with 0 pneumonia to Luton and Dunstable Hospital under the care of Dr T. Parkinson. Severe osteomalacia was shown to be due to a generalized renal tubular defect (Lavelle, 1964) and the patient $\sigma$ was transferred with a diagnosis of Wilson's N disease to the National Hospital for Nervous $\underset{\mathrm{C}}{\mathcal{S}}$ Diseases under the care of $\operatorname{Dr} D$. Brinton and Professor J. N. Cumings.

In 1964 , when aged 41 , the patient was an

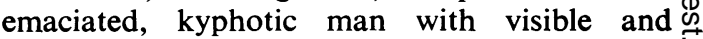
palpable protuberances at the costochondral 0 junctions and on the ribs in the midaxillary line, $\overrightarrow{0}$ with a painless, palpable fracture dislocation of the blade of the right scapula.

His behaviour was facile and uninhibited. There was slight titubation of the head, an irregular flapping tremor of the extended hands, which persisted throughout intended movements, a 
slurred dysarthria, and dancing movements of the eyes for a few seconds on fixation but no nystagmus. His gait was slow and shuffling, and he required assistance since he was unable to make any correcting movements to prevent himself falling. Tone was increased in the limbs, tendon reflexes were brisk, and cutaneous responses normal. The only weakness was of hip movement, and this was difficult to assess due to pain. Kayser-Fleischer rings were present.

A radiological skeletal survey showed gross

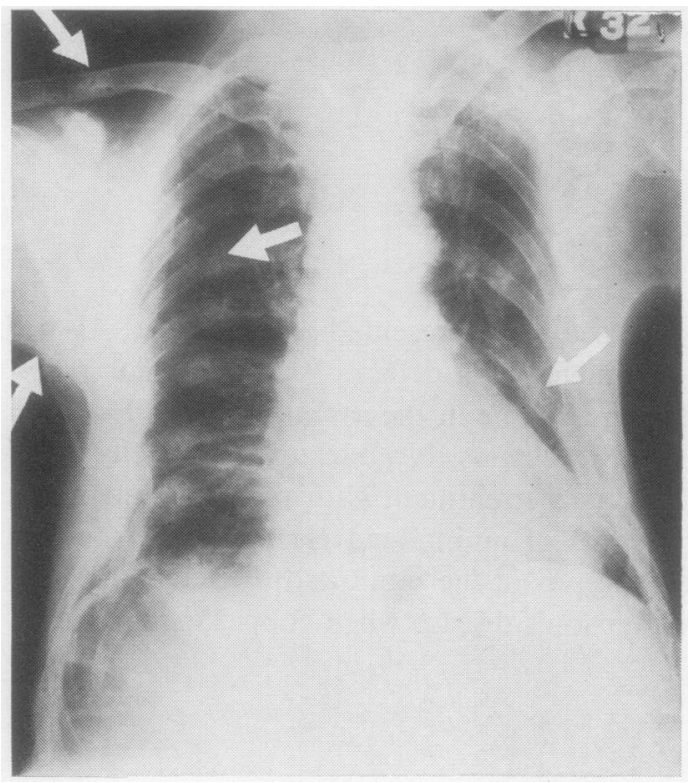

Fig. 1 Chest radiograph in 1964. Arrows indicate some of the pseudo-fracture sites. osteomalacia with demineralization and defor角ities due to multiple pseudo-fractures in the rifo, the right scapula, both clavicles (Fig. 1), both pubic and ischial rami, the left ilium, the shaft of the right femur, and the metatarsal bones. Jaws and teeth were normal. Two radioopaque calculi were shown on intravenous pyelograms in the renal calyces.

Plasma urea was 38 to $87 \mathrm{mg} / 100 \mathrm{ml}$; alkal $\frac{\overline{\frac{N}{7}}}{\mathrm{e}}$ phosphatase $16 \mathrm{~K}$-A units; serum Ca $8 \cdot 2 \mathrm{mg} / 100 \mathrm{r}$, inorganic phosphate $2 \cdot 7 \mathrm{mg} / 100 \mathrm{ml}$; uric aểd $1.8 \mathrm{mg} / 100 \mathrm{ml}$; copper $44 \mu \mathrm{g} / 100 \mathrm{ml}$ (normal $85-115 \mu \mathrm{g} / 100 \mathrm{ml})$; copper oxidase 13 microlities $\mathrm{O}_{2} / \mathrm{ml} /$ hour (normal 100-150). The plasma levebs of $\mathrm{Na}$ were $142, \mathrm{~K} \mathrm{3} \cdot 2, \mathrm{Cl} 103$, and alkali reserve $22 \mathrm{~m}$-equiv/litre. Flocculation tests, the prothrombin index, and bilirubin were norma Protein was $6.5 \mathrm{mg} / 100 \mathrm{ml}$ with a slight decrease in albumin on electrophoretic strips.

Glucose was found in the urine, and a chromato gram showed marked generalized aminoacidurn. Amino-acid clearances were measured as dedscribed by Cusworth and Dent (1960a), and ame shown in the Table; a protein electrophoretic strip showed the pattern seen in renal tubular dyfunction. A 24-hour urine collection showed copper $32 \mu \mathrm{g}$ (normal up to $50 \mu \mathrm{g}$ ); amino-acid nitrogen $530 \mathrm{mg}$ (normal $267-431 \mathrm{mg}$ ); calcium from 72 to $325 \mathrm{mg}$; and phosphate 212 to $772 \mathrm{mg}$.

The patient was transferred to Universisy College Hospital under the care of Profess C. E. Dent for investigation and management of the disturbance of calcium metabolism and renâl function. Penicillamine, $150 \mathrm{mg}$ eight hourly, åd calciferol $1 \mathrm{mg}$ twice a day, were started 萧 August 1964; calciferol was reduced to $1 \mathrm{mg} \exists \mathrm{a}$ day in March 1966 when the serum calcium level

\begin{tabular}{|c|c|c|c|c|c|c|c|}
\hline \multirow[t]{2}{*}{ Amino Acid } & \multicolumn{3}{|c|}{10 August 1964} & \multicolumn{4}{|c|}{3 August 1968} \\
\hline & $\begin{array}{l}\text { Plasma } \\
(\mathrm{mg} / 100 \mathrm{ml})\end{array}$ & $\begin{array}{l}\text { Urine } \\
\text { Excretion } \\
(\mu g / \min )\end{array}$ & $\begin{array}{l}\text { Renal } \\
\text { Clearance } \\
(\text { ml } / \text { min })\end{array}$ & $\begin{array}{l}\text { Plasma } \\
(\mathrm{mg} / \mathrm{l} 00 \mathrm{ml})\end{array}$ & $\begin{array}{l}\text { Urine } \\
\text { Excretion } \\
(\mu g / \text { min })\end{array}$ & $\begin{array}{l}\text { Renal } \\
\text { Clearance } \\
(\text { ml/min })\end{array}$ & $\begin{array}{l}\text { Renal Clearanc } \\
\text { in Normal } \\
\text { Subjects }\end{array}$ \\
\hline Taurine & $1 \cdot 0$ & 116 & $11 \cdot 1$ & 0.7 & $2 \cdot 3$ & $0 \cdot 3$ & $1 \cdot 7-26$ \\
\hline Aspartic & $0 \cdot 1$ & 6 & 6.0 & $0 \cdot 2$ & $1 \cdot 7$ & 0.5 & Trace $-8 \cdot 8$ \\
\hline Threonine & $2 \cdot 6$ & 311 & $12 \cdot 0$ & $1 \cdot 8$ & 59 & $3 \cdot 2$ & $0 \cdot 5-2 \cdot 5$ \\
\hline Serine & $1 \cdot 2$ & 203 & $16.9\}$ & & & & $1 \cdot 2-3 \cdot 4$ \\
\hline Glutamine & -3 & - & $-\}$ & $8 \cdot 4$ & 137 & $1 \cdot 6$ & $0 \cdot 1-2 \cdot 3$ \\
\hline Proline & $2 \cdot 0$ & 13 & 0.6 & - & - & & 0 \\
\hline Glycine & $3 \cdot 1$ & 386 & $12 \cdot 5$ & $2 \cdot 1$ & 75 & $3 \cdot 6$ & $1 \cdot 2-8 \cdot 6$ \\
\hline Alanine & 1.9 & 89 & $4 \cdot 7$ & 2.6 & 24 & 0.9 & $0 \cdot 2-1 \cdot 3$ \\
\hline a-Amino-butyric & 0.6 & 81 & $13 \cdot 5$ & 0.7 & 93 & $13 \cdot 6$ & $0.7-2.9$ \\
\hline \multicolumn{8}{|c|}{ Cystine $\quad\}$} \\
\hline Valine & $2 \cdot 8$ & 41 & $1 \cdot 4$ & $2 \cdot 2$ & - & - & $0 \cdot 1-0.3$ \\
\hline Methionine & 0.3 & - & & 0.6 & 0.7 & $0 \cdot 1$ & $1 \cdot 0-3 \cdot 4$ \\
\hline Isoleucine & $1 \cdot 0$ & 10 & $1 \cdot 0$ & 0.8 & $2 \cdot 6$ & $0 \cdot 3$ & $0 \cdot 2-1 \cdot 0$ \\
\hline Leucine & $1 \cdot 8$ & 19 & $1 \cdot 1$ & 1.6 & 3.6 & 0.2 & $0 \cdot 2-0.9$ \\
\hline Tyrosine & 0.8 & 62 & $7 \cdot 7$ & 0.9 & $12 \cdot 0$ & $1 \cdot 3$ & $0 \cdot 8-3 \cdot 3$ \\
\hline Phenylalanine & $1 \cdot 1$ & 35 & $3 \cdot 2$ & $1 \cdot 1$ & $5 \cdot 7$ & 0.5 & $0 \cdot 3-2 \cdot 3$ \\
\hline Ornithine & $1 \cdot 3$ & 240 & $13 \cdot 3$ & $1 \cdot 8$ & 43 & $2 \cdot 4$ & $0 \cdot 2-0 \cdot 8$ \\
\hline Lysine & $2 \cdot 6$ & 449 & $17 \cdot 3$ & $2 \cdot 7$ & 114 & $4 \cdot 2$ & $0 \cdot 3-2 \cdot 4$ \\
\hline Histidine $\}$ & & & & $1 \cdot 2$ & 63 & $5 \cdot 7$ & $1 \cdot 9-22$ \\
\hline Arginine & $1 \cdot 0$ & 72 & $7 \cdot 2$ & $2 \cdot 7$ & 30 & $1 \cdot 1$ & $0 \cdot 15-1 \cdot 2$ \\
\hline
\end{tabular}

Table Amino-acid clearance before and after four years' treatment with penicillamine ${ }^{1}$

${ }^{1}$ Clearances measured as described by Cusworth and Dent (1960) except that an automatic analyzer was used.

${ }^{2}$ Range in four normal adults (Cusworth and Dent, 1960) and nine normal children (Scriver and Davies, 1965).

${ }^{3}$ - indicates amino acid not determined for technical reasons. 
rose to $11.6 \mathrm{mg} / 100 \mathrm{ml}$. Clinically improvement was steady, bone tenderness disappeared, walking improved, and by August 1968 the only abnormalities were a rather broad-based gait with some unsteadiness on turning, mild dysarthria, slight clumsiness on hand movements, and persistent euphoria. Healing of the pseudo-fractures was shown on radiographs in November 1965, and was complete by August 1968 (Fig. 2). The alkaline phosphatase level rose to $23 \mathrm{~K}$-A units during the first five months of treatment and thereafter fell, remaining below $4 \mathrm{~K}-\mathrm{A}$ units after September 1967. On starting treatment, urine copper levels rose to $1,310 \mathrm{mg} / 24$ hours.

Investigations in 1968 showed serum copper $60 \mu \mathrm{g} / 100 \mathrm{ml}$; caeruloplasmin $5 \mathrm{mg} / 100 \mathrm{ml}$ (normal 20 to 40 ); serum calcium $10 \mathrm{mg} / 100 \mathrm{ml}$; inorganic phosphate $2.5 \mathrm{mg} / 100 \mathrm{ml}$; and uric acid $2.4 \mathrm{mg} / 100 \mathrm{ml}$. Plasma urea was $67 \mathrm{mg} / 100 \mathrm{ml}$ and alkaline phosphatase $4 \mathrm{~K}-\mathrm{A}$ units. Urine contained glucose and a trace of protein. Urine amino-acid chromatograms were unchanged, and amino-acid clearances as shown in the Table. Urine acidification showed a minimum $p \mathrm{H}$ of 5.2 after an ammonium chloride load, and maximum ammonium production of $25 \mu$-equiv/ minute. Renal radiographs showed that radioopaque deposits appeared to have increased in size since 1964 .

\section{Discussion}

Uzman and Denny-Brown (1948) demonstrated that patients with Wilson's disease presenting with either cerebral or liver dysfunction may excrete increased quantities of amino acid in their urine. It has since been recognized that this aminoaciduria results from impaired proximal renal tubular reabsorption (Cooper, Eckhardt, Faloon, and Davidson, 1950) which may also produce glycosuria, hyperphosphaturia, hyperkaliuria, hypercalcuria, tubular proteinuria, and uricosuria, that is, the group of tubular dysfunctions usually going by the name of the 'Fanconi syndrome'. Failure of urine acidification may also be present as the result of the impaired distal tubular function (Cusworth and Dent, 1960b). The renal abnormality is symptomless unless phosphate loss is sufficient to produce rickets or osteomalacia. The latter was found in mild degree in seven of 20 patients surveyed radiologically by Finby and Bearn (1958), in one of 10 patients reported by Feng (1957), and in one of six patients described by Cooper et al (1950). There have been only four previous patients described with Wilson's disease in whom the bone disease was the predominant feature. Warnock (1952) described an 8-year-old boy with peritonitis, 'osteoporosis and pseudo-fractures'; Cavallino and Grossman (1968) reported an 8-year-old boy who developed a neurological disturbance and

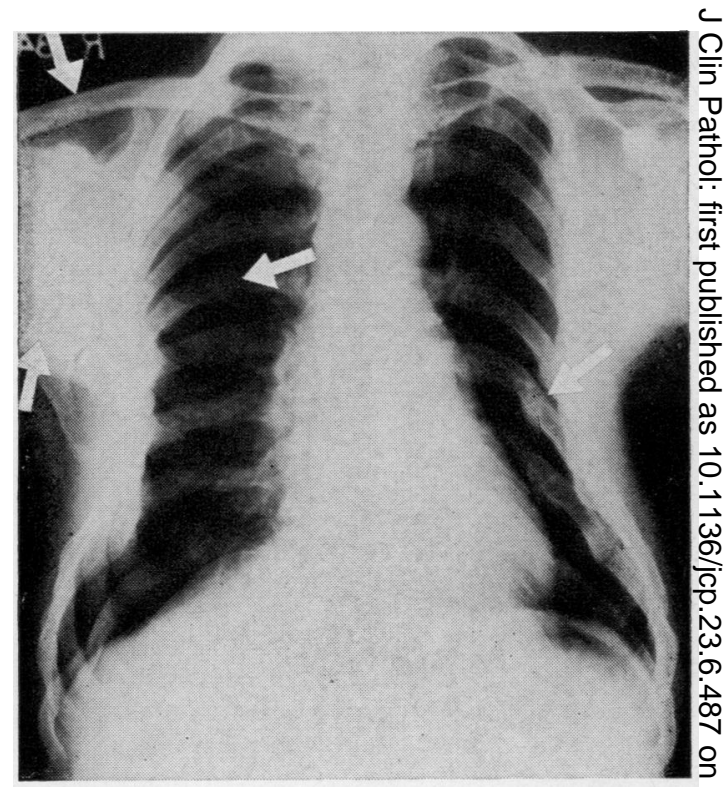

Fig. 2 Chest radiograph in 1968. Arrows indicate some of the sites of healed pseudo-fractures.

was diagnosed as Wilson's disease four years phosphataemia, and hypocalcuria; Morgan, Stewart, Lowe, Stowers, and Johnstone (1962) give full metabolic details of a similar case in which rickets in a 17-year-old preceded the neurological disorder by three years. The case of $\stackrel{\mathbb{Q}}{\mathscr{Q}}$ 'adult Fanconi syndrome' (Dent and Stowers, $\overrightarrow{\vec{O}}$ 1965) was also diagnosed as having Wilson's 3 disease 18 years after the original description.

In the present case, although there was some evidence of cerebral disturbance starting in the third decade, the predominant feature at 41 ? years of age was gross osteomalacia. The investigations show evidence of failure of proximal renal tubular reabsorption, and, although the serum $\frac{\rho}{3}$ alkali reserve was normal, the maximum ammonium production after an ammonium 9 chloride load was low in 1968 even after treatment $\frac{7}{0}$ with penicillamine. Hypercalcuria has been reported in Wilson's disease (Morgan et al, $N$ 1962; Litin, Randall, Goldstein, Power, and Diessner, 1959; Playoust and Dale, 1961), but ${ }_{N}$ in this case the 24-hour calcium excretion never ${ }_{\sigma}^{\mathrm{C}}$ rose above $325 \mathrm{mg} / 100 \mathrm{ml}$.

Despite the very marked bone disease the serum alkaline phosphatase was only slightly raised at $16 \mathrm{~K}-\mathrm{A}$ units, and even during healing never rose above $23 \mathrm{~K}$-A units. It is unlikely that ${ }_{0}^{-}$ these relatively low values were due to inter- $\vec{D}$ ference in enzyme activity by high serum copper $\frac{?}{0}$ levels, since, in the few reports of bone disorder in Wilson's disease in which this enzyme has been? measured, an increase in activity compatible witho the severity of the bone disorder has been shown; 
moreover experiments were performed in vitro and it was shown that alkaline phosphatase activity was not inhibited by copper. It is possible that the low values in this patient are due to the additional inherited defect of hypophosphatasaemia perhaps due to his being a heterozygote for hypophosphatasia, since when the osteomalacia was cured the serum alkaline phosphatase fell and has remained below normal male levels (Dent and Harper, 1962). If this is so, then the double pathology may have contributed to the multiplicity and severity of the painless pseudofractures, despite the fact that the patient was never severely hypophosphataemic, and to the rather poor remodelling seen on healing.

This patient had renal stones, an unusual finding in the presence of osteomalacia, when the bone disease is due to Fanconi's syndrome. It has been suggested that amino acids in the urine inhibit stone formation by increasing the solubility of calcium and magnesium phosphate, as shown in vitro by McGeown (1959). The only previous reports of renal stones in Wilson's disease are those of two out of five patients described by Litin et al (1959) and one by Rosenoer and Michell (1959). All of these patients had low serum phosphate levels, increased aminoaciduria, and failure of urine acidification. The presence of a renal stone does not necessarily imply that the stone was formed when the urine amino-acid content was high, since stone formation may have preceded development of generalized renal tubular dysfunction. Nephrocalcinosis has been described in Wilson's disease (Litin et al, 1959), and Fulop, Sternlieb, and Scheinberg (1968) demonstrated the development of nephrocalcinosis while on treatment. In the present patient the only change in renal radiography after four years' treatment was a suggestion of an increase in size of the radioopaque deposits.

Abnormal renal function is not invariably found in patients with Wilson's disease, thus indicating that the renal lesion is unlikely to be the primary cause of the disorder as was at one time postulated. The demonstration of kidney copper content up to 10 times normal (Bickel, Neale, and Hall, 1957; Wolff, 1964) suggests that here, as in the brain and liver, the disordered function is caused by the copper. Further support for this thesis is provided by the observation that similar renal tubular defects have been produced in man by other metals, notably cadmium (Kazantzis, Flynn, Spowage, and Trott, 1963), and by the damage seen in rat proximal and distal renal tubules after poisoning by copper (Wolff, 1960). Not every patient with Wilson's disease has histological changes in the kidney (Gilsanz, Barrera, and Anaya, 1960), although there have been a number of reports of focal epithelial damage in the proximal convoluted tubule. Reynolds, Tannen, and Tyler (1966) and Wolff (1964) showed deposition of copper in the epithelial cells but poor correlation between sites of copper staining and of histological damage Walshe (1968) has shown that removal of copper may result in improvement in the distal tubula function of urine acidification, and the report of patient who showed a decrease in the amount of glucose, uric acid, and amino acid excreted after prolonged treatment for Wilson's disease (Fulop et al, 1968) indicated that at least some of the disturbance of proximal tubular function might also be reversible, but detailed clearance studi have not previously been reported. In the present case, the Table shows that after four years' treaft ment with penicillamine theaminoacid clearances have fallen considerably. In 1964 the clearances for 12 of the amino acids measured were marked raised compared with the values found in foif normal adults (Cusworth and Dent, 1960a) and in nine children (Scriver and Davies, 1965), where岁 by 1968 , with the exception of ornithine and cystine, the clearances all fell within the abover mentioned normal range. Since plasma levels of amino acids have not altered significantly the decreased clearances reflect a change in rengl function either due to a decrease in glomerular filtration rate (GFR) or to improved tubula reabsorption. It is known that in Wilsond disease the glomerular filtration rate may be decreased (Bearn, Yu, and Gutman, 1957 Rates in this patient in 1964 were not measure⿻ but in 1968 the glomerular filtration rate, as measured by inulin clearance immediately afte amino-acid clearance studies, gave a mean figure of $32 \mathrm{ml} / \mathrm{minute}$. In order to account for the decreased amino acid clearance in 1968 by change in glomerular filtration rate a fall in $\frac{9}{4}$ must be postulated occurring over four yea while copper was being removed and during which no significant change in blood urea occurred. more likely explanation is that the change in amino acid clearance after copper removal reflects an increased tubular reabsorption. If this was then the impairment of tubular function wh secondary to the deposition of copper.

The factors determining the relative rate of copper deposition in brain, liver, or kidney $\$$ various ages are not known. We are not therefore able to foretell the age and disability with which? patient with Wilson's disease is likely to present

I am most grateful to Dr D. Brinton, Professe J. N. Cumings, Professor C. E. Dent, and Dr T. Parkinson for their permission to publis⿱⺈⿸⿻口丿乚厶 this case, to Professor Dent, Dr D. C. Cuswort产, and Dr T. C. B. Stamp, who performed tịe investigations of calcium metabolism and rend function, and to Professor J. N. Cumings wh studied the copper metabolism. I should al\$ like to thank Dr Cusworth who estimated arigd calculated the amino-acid clearances. This case was presented to the Clinical Section of the Royal Society of Medicine in July 1964, and \$o the Neurological Section in November 1964. 
References

Bearn, A. G., Yu, T. F., and Gutman, A. B. (1957). Renal function in Wilson's disease. J. clin. Invest., 36, 1107-1114.

Bickel, H., Neale, F. C., and Hall, G. (1957). A clinical and biochemical study of hepato-lenticular degeneration. Quart. J. Med., n.s., 26, 527-558.

Cavallino, R., and Grossman, H.(1968). Wilson's disease presenting with rickets. Radiology, 90, 493-494.

Cooper, A. M., Eckhardt, R. D., Faloon, W. W., and Davidson, C. S. (1950). Investigation of the aminoaciduria in Wilson's disease: demonstration of defect in renal function. J. clin. Invest., 29, 265-278.

Cusworth, D. C., and Dent, C. E. (1960a). Renal clearances of amino-acids in normal adults and in patients with aminoaciduria. Biochem. J., 74, 550-561.

Dent, C. E., and Cusworth, D. C. (1960b). In Biology of Pyelonephritis, edited by E. L. Quinn and E. H. Kass, p. 535. Little Brown, Boston.

Dent, C. E., and Harper, C. M. (1962). Plasma alkaline-phosphatase in normal adults and in patients with primary hyperparathyroidism. Lancet, 1, 559-563.

Dent, C. E., and Stowers, J. M. (1965). Adult Fanconi syndrome and cirrhosis. Brit. med. J.,1,520.

Feng, Y. K. (1957). Wilson's disease. Report of ten cases. Chinese med. J., 75, 631-655.

Finby, N., and Bean, A. G. (1958). Roentgenographic abnormalities of the skeletal system in Wilson's disease. Amer. J. Roentgen., 79, 603-611.

Fulop, M., Sternlieb, I., and Scheinberg, I. H. (1968). Defective urinary acidification in Wilson's disease. Ann. intern. Med. 68, 770-777.

Gilsanz, V., Barrera, A., and Anaya, A. (1960). The renal biopsy in Wilson's disease. Arch. intern. Med., 105, 758-761.

Kazantzis, G., Flynn, F. V., Spowage, J. S., and Trott, D. G. (1963). Renal tubular malfunction and pulmonary emphysema in cadmum pigment workers. Quart. J. Med., 32, 165-192.
Lavelle, M. I. (1964). Fanconi's syndrome. Proc. roy. Soc. Med., 57, 592-594.

Litin, R. B., Randall, R. V., Goldstein, N. P., Power, M. H., and Diessner, G. R. (1959). Hypercalciuria in hepatolenticular degeneration. Amer. J. med. Sci., 238, 614-620.

McGeown, M. (1959). The urinary excretion of aminoacids in calculus patients. Clin. Sci., 18, 185-194.

Morgan, H. G., Stewart, W. K., Lowe. K. G., Stowers, J. M., and Johnstone, J. H. (1962). Wilson's Disease and the Fanconi syndrome. Quart. J. Med., 31, 361-384.

Playoust, M. R., Dale, N. E. (1961). Metabolic balance studies in a patient with Wilson's Disease and hypercalcuria. Metabolism, 10, 304-314.

Reynolds, E. S., Tannen, R. L., and Tyler, H. R. (1966). The renal lesion in Wilson's Disease. Amer. J. Med., 40, 518-527.

Rosenoer, V. M., and Michell, R. C. (1959).! Skeletal changes in Wilson's disease. Brit. J. Radiol., 32, 805-809.

Stowers, J. M., and Dent, C. E. (1947). Studies on the mechanism $\vec{O}$ of the Fanconi syndrome. Quart. J. Med., 16, 275-290.

Scriver, C. R., and Davies, E. (1965). Endogenous renal clearance $\vec{\omega}$ rates of free amino-acids in pre-pubertal children. Paedi- $Q$ atric.s, 36, 592-598.

Uzman, L., and Denny-Brown, D. (1948). Amino-aciduria in hepato-lenticular degeneration. Amer. J. Med. Sci., 215, iN 599-611.

Walshe, J. M. (1968). Effect of penicillamine on failure of renal acidification in Wilson's disease. Lancet, 1, 775-779.

Warnock, C. G. (1952). Hepatolenticular degeneration. Ulster med. J., 21, 155-171.

Wolff, S. M. (1960). Copper deposition in the rat. Arch. Path., 을 69, 217-223.

Wolff, S. M. (1964). Renal lesions in Wilson's disease. Lancet, $\mathcal{S}$ $1,843-845$.

\section{The July 1970 Issue}

\section{THE JULY 1970 ISSUE CONTAINS THE FOLLOWING PAPERS}

Megaloblastic anaemia of pregnancy: A clinical and laboratory study with particular reference to the total and labile serum folate levels

P. G. RAE AND P. M. ROBB

A haematological study of patients receiving longterm treatment with trimethoprim and sulphonamide G. C. JENKINS, D. T. D. HUGHES, AND P. C. HALL

Red cell survival in biliary cirrhosis R. HUME, J. M. WILLIAMSON, AND J. W. WHITELAW

Relationships between platelet function tests in normal and uraemic subjects A. A. HASSANEIN, G. P. MCNICOL, AND A. S. DOUGLAS

The irrelevance of adhesive platelet estimations after thrombosis R. D. EASTHAM

The application of tetrazolium bioautography to the identification of folic acid derivatives R. J. LEEMING, HEATHER PORTMAN-GRAHAM, C. H. J. SWAN, AND J. A. BLAIR

A composite malignant tumour of the elderly female breast D. M. WAYTE, J. B. STEWART, AND C. G. MCKENZIE

Sensitivity of Nocardia to trimethoprim and sulphonamides in vitro WILLIAM A. BLACK
Tetracycline levels in bronchial secretions M. J. CAMPBELL

Barbiturate blood levels found at necropsy in proven cases of acute barbiturate poisoning ROGER GILLETT AND FRANK G. WARBURTON

An assessment of an automated fluorimetric blood phenylalanine technique for phenylketonuria screening and for accurate estimations J. B. HOLTON AND P. M. WEST

Noise levels in a clinical chemistry laboratory P. D. GRIFFITHS, R. L. KELL, AND W. TAYLOR

\section{Technical methods}

Flexible electrophoresis applicator for use with the AutoAnalyzer in routine protein analysis M. E. CARRUTHERS

A simple high-speed recording colorimeter system G. B. TENNANT AND J. L. WITHEY

Obituary/Professor Nuala Crowley

Letter to the Editor

Book reviews

Copies are still available and may be obtained from the PUBLISHING MANAGER, BRITISH MEDICAL ASSOCIATION, TAVISTOCK SQUARE, WC1H 9JR price 22/6. 